\title{
US unlikely to swallow plan for a food safety supremo
}

[WASHINGTON] The three heads of a new presidential council appear unlikely to act on a call for a single authority to be put in charge of the US government's food safety efforts.

The President's Council on Food Safety must respond to the report, by the Institute of Medicine and the National Research Council, within six months. At a recent press conference the joint chairs - Donna Shalala, the Secretary of Health and Human Services; Dan Glickman, the Secretary of Agriculture; and Neal Lane, the Assistant to the President for Science and Technology - pledged to consider its recommendations seriously.

But their comments made clear that they are unlikely to embrace its proposal for a single, powerful official, possibly heading a unified agency. The report recommended that a presidentially appointed official should control the country's food safety budget and policy, to unify and render science-based what it called a fragmented system "in critical need of attention" (see Nature 394, 822; 1998).

The three chairs say that existing policies need to be coordinated. "What we're interested in is ratcheting up and improving the quality of food safety ... not automatically [concluding] that what you need is a powerful new bureaucracy," said Shalala.

Lane said that too many different fields of science were involved. "You can't expect all that to appear in one agency. First, it would be huge, and second, you would have pulled all the pieces out of the other agencies that need these ... scientific and technological underpinnings for their own missions."

Within a week of the report's release President Clinton responded by establishing the Council on Food Safety, charging it with coordinating the efforts of a dozen US agencies involved in ensuring food safety.

In addition to its three co-chairs, the council includes five cabinet-level and White House officials. It will be responsible for developing a "comprehensive strategic plan" for national food safety — taking into account the report's recommendations and will present a unified budget to Congress. But it will not have control over food safety funds; this remains with the agencies.

Opposition to the single-agency idea goes beyond the council. Political observers widely agree that the Republican Congress would be highly unlikely to enact a law establishing a food safety bureaucracy or leader. The idea is also opposed by the food industry.

"The President can't really do what the [National Research Council] has recommended without help from Congress. so the Clinton administration is going as far as it can" by establishing the council, says Caroline Smith DeWaal, director of food safety at the Center for Science in the Public Interest.

Timothy Willard, of the National Food Processors Association, says the new council is a step forward. "We're supportive as much of what wasn't done as what was done in creating this," he says.

Meredith Wadman

\section{Controversial appointment to SA council}

[CAPE TOWN] Malegapuru William Makgoba, 45 , a research professor at the University of the Witwatersrand, has been appointed president of South Africa's Medical Research Council (MRC) for a five-year term from next year. He replaces retiring incumbent Wally Prozesky.

Makgoba was at the centre of a fierce controversy in 1995 after allegations of incompetence, falsifying his curriculum vitae and disloyalty to his institute were made against him by 13 of the Witwatersrand's senior academics (see Nature 378, 324; 1995).

The former immunologist at the Royal Hammersmith Postgraduate Medical School in London became deputy vice-chancellor of the Witwatersrand in 1994, and was tipped to become vice-chancellor. But following the controversy he was transferred to a research chair in molecular immunology in 1996 for the remainder of his five-year contract with the university.

Makgoba's appointment at the MRC was

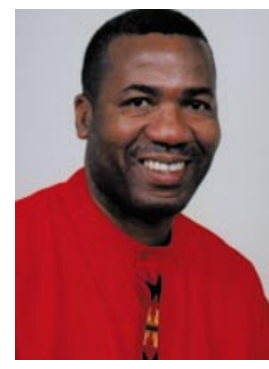

Makgoba: survived controversy at the Witwatersrand to lead the MRC.

unusual since he was chair of the MRC board. He resigned from this post after applying to be MRC president. The selection process was conducted by the deputy chair of the MRC board, Marian Jacobs, who succeeds Makgoba as chair.

Jacobs, who is head of the Child Health Unit at the University of Cape Town, said that Makgoba had been chosen unanimously by the board after indepth interviews and public lectures by three candidates.

Makgoba says his priorities as the MRC's president will be improving social cohesion, building capacity and promoting interdisciplinary research.

\section{Row in India over rules on animal experiments}

[NEW DELHI] The National Academy of Sciences of India has urged the prime minister to intervene to prevent the implementation of new rules on using animals in research.

The controversial rules, which scientists say would strangle research with red tape, were framed by a committee led by Maneka Gandhi, minister for welfare and an ardent animal activist (see Nature 394, 516; 1998).

"Some of the rules formulated by this committee are likely to stall essential animalbased research rather than regulating it rationally," Prakash Tendon, the academy's president, told the prime minister.

Heads of India's biomedical research agencies and secretaries of scientific departments who met last week agreed unanimously that the legislation should be reversed. In a letter to Gandhi, Nirmal Ganguli, chief of the Indian Council of Medical Research (ICMR), warned of "far-reaching consequences" if the rules were implemented, and strongly urged her to wait until they had been debated by the scientific community.

Under the new regulations, no research institute would be able to acquire animals without the committee's permission, or begin any experiment without its clearance. Funding agencies like ICMR would have to submit detailed monthly reports of the experiments they are funding and the number of animals used. Researchers would not be allowed to import animals.

"If the guidelines are accepted by the government, much biological research in India will come to a standstill as scientists grapple with a mountain of red tape," said the Indian journal Current Science in an editorial. Gandhi, however, argues that scientists are killing animals unnecessarily, especially in research by pharmaceutical companies.

Vulimiri Ramalingaswami, former president of ICMR and now professor at the AllIndia Institute of Medical Sciences in New Delhi, says that instead of framing new rules the committee should strengthen existing guidelines "that are working reasonably well". At present, each research institute has an animal ethical committee that follows the guidelines specified in the 1960 Prevention of Cruelty to Animals Act.

Nitya Nand, former director of the Central Drug Research Institute in Lucknow, says the new rules are "most unimaginative, coming at a time when our laboratories are struggling hard to be internationally competitive". He says the committee should have just laid down guidelines for animal housing and husbandry to minimize pain and suffering: "All other functions should be left to institute ethical committees."
K.S.Jayaraman 